\title{
Alumina sludge's Influence on the physicochemical characteristics of $\mathrm{CPJ}_{55}$ cement
}

\author{
M. Dahhou ${ }^{1, *}$, R. Barbach ${ }^{2}$ and M. El Moussaouiti ${ }^{1, *}$ \\ ${ }^{1}$ Laboratory of Materials, Nanotechnology and Environment, Department of Chemistry, Faculty of Science, \\ Mohammed V University Rabat, Morocco. \\ ${ }^{2}$ Asment Temara (Groupe Votorantim) Ain Atig-Temara, Rabat, Morocco. \\ *Corresponding authors. \\ mohammeddahhou@gmail.com (M. Dahhou),m.elmoussaouiti@gmail.com (M. El Moussaouiti).
}

\begin{abstract}
Partial replacement of the Portland cement $\mathrm{CPJ}_{55}$ ingredients by various quantities of alumina sludge (AS), produced during drinking water plant sludge, was used in the preparation of mortar mold with dimensions $40 \times 40 \times 160 \mathrm{~mm}$. The characterization of materials is carried out by X-ray fluorescence (XRF), Xray diffraction (XRD), free lime dosing, and the mechanical tests. Analysis of the chemical composition by $\mathrm{XRF}$ shows that the studied alumina sludge is mainly composed of aluminum oxide, silica, which is correlated with the principal mineral phases identified in the XRD analysis results. It is demonstrated that adding 5\% of the alumina sludge in Portland cement does not affect the mineralogy of final product. Nevertheless, the compression and flexural strength tests (in 28 days) conducted on mortar sample comprising 5\% sludge elucidate that it belongs to cement mortar class of type $32.5 \mathrm{R}$.
\end{abstract}

Keywords: Waste management, alumina sludge, cement

\section{Introduction}

Drinking water treatment plants produce annually thousands of tons of mineral waste called alumina sludge; attributed to the addition of aluminum sulphate during the water coagulation-flocculation step. The latter are mostly discharged to landfills, being the least costly disposal method, which can possibly cause serious environmental problems [1,2]. The pulverized state of the sludge of about $20 \%$ dryness requiring no grinding is a saving in energy costs for the cement industries in particular. In addition, their recycling in this way addresses the environmental protection issues [1-4].

Several studies have examined the replacement of raw precursors in the preparation of building materials by alumina sludge or sewage sludge. It was pointed out that the clinker microstructures and the possible physicochemical properties of ecological cements are strongly influenced by the quantities of sludge $[1,5]$. According to Zamora et al. [6] it is quite feasible to use alumina sludge from the northern region of Mexico as an additional cementing material and substitute for sand to prepare mortars and concretes for employing in the construction industry. In accordance with Yan et al. [7], the addition of $2.5 \%$ by weight of de-inking sludge in the cement mortar does not significantly affect their physical and mechanical characteristics. Although, the replacement of $20 \%$ de-inking sludge by weight of cement significantly affects the resistance of the mortars which strongly favors the incorporation potential of the de-inking sludge into cement. Rodriguez, et al. [8] studied the effect of the addition of 5 to $30 \%$ of alumina sludge on the physicochemical characterization and the microstructure of the cement mortar 42.5 R. The partial replacement of the cement by the alumina sludge in this case is characterized by the decrease resistance of mortars. Another study by Rodriguez et al. [9] reports that replacement of $20 \%$ constituents of cement type $42.5 \mathrm{~N}$ with the sludge enriched with $\mathrm{SiO}_{2}, \mathrm{Al}_{2} \mathrm{O}_{3}$ and $\mathrm{Fe}_{2} \mathrm{O}_{3}$ contents produces $32.5 \mathrm{R}$ grade cements. According to El Didamony et al. [10] compressive strength increases with the addition of the alumina sludge up to $5 \%$, and then decreases with its increase to $15 \%$ by weight. In this case the addition of the alumina sludge up to $5 \%$ can act as a nucleating agent, which gives greater compressive strength at different curing ages. For Piasta and Lukawska, replacement of the cement with 10 or $20 \%$ ash from the sewage sludge resulted in an extension of the setting times. The chemical composition suggests that the prolongation in setting times may be due to the appearance of phosphorus in sewage sludge ash. The standard compressive strength of mortars of $10 \%$ and $20 \%$ ash of sewage sludge is lower than that of reference mortar [11].

This work is a contribution towards exploring the new opportunities to recycle alumina sludge by replacing with it certain proportions of cement ingredients. It will eventually lead to preventing environmental pollution and sustainable development. 


\section{Materials and methods}

Various loadings of alumina sludge were used in our study for the preparation of mortars. In view of comparison, the standard $\mathrm{CPJ}_{55}$ cements of type $52.5 \mathrm{~N}$ were employed. The cements on which we conducted our study were prepared according to the process of production designed in Moroccan cement. A ball mill was used to grind the components (80\% clinker, $17 \%$ limestone and $3 \%$ gypsum), to obtain the required $\mathrm{CPJ}_{55}$ cement.

Chemical analyses were carried out by a fluorescence spectrometer X Panalytical PW 4400/24. The samples to be analyzed were prepared as beads using lithium tetraborate as a flux.

Mineralogical compositions were assessed by X-ray diffraction, using a diffractometer X'Pert Pro MPD PANalytical. This diffractometer contains a copper anticathode $(\mathrm{Cu}-\mathrm{K} \alpha)$ with wavelength $\lambda=1.54 \AA$, supplied with a potential of $45 \mathrm{KV}$ and a current of 40 $\mathrm{mA}$. The recordings were made with a pitch of $0.06(2 \theta)$ and a counting time of 121 seconds per step.

Chemical analysis by conventional dosage with the glycerol-alcohol method was performed to determine the contents of free lime in cement.

Resistance to flexural and compressive strength of the mortar obtained was determined by using prismatic mold with a cross section of $40 \mathrm{~mm} \times 40 \mathrm{~mm}$ and a length of $160 \mathrm{~mm}$, comprising three horizontal compartments, in order to simultaneously handle three samples. We used normal mortars according to EN197-1 [12] of the following composition:

- $450 \mathrm{~g}$ of binder, the additions are always introduced in substitution of cement (C);

- $1350 \mathrm{~g}$ of standardized sand (S);

- $225 \mathrm{ml}$ of water (W).

The level of the mixing water was kept constant for all the mixtures $\mathrm{W} / \mathrm{C}=0.5$. The flexural strength and compression were tested after 2, 7 and 28 days [12]. The different mortars studied and their notations are as followings:

-CM: Control mortar: $\mathrm{CPJ}_{55}$ cement of type CEM $52.5 \mathrm{~N}$; - CM X: Cement mortar $\mathrm{CPJ}_{55}+\mathrm{X} \%$ of dried alumina sludge at $105^{\circ} \mathrm{C} ; \mathrm{X}: 5 \%-25 \%$.

The mineralogical phases of the cements were calculated by the estimates derived from Bogue's equations according to the expressions (1) - (4) [13]:

Table 1. Chemical composition of alumina sludge.

$$
\begin{aligned}
& \mathrm{C}_{3} \mathrm{~S}(\%)=4.07 \times\left[\mathrm{C}-(0.7 \times \mathrm{S})-\left(1.27 \times(\mathrm{LOI} / 2)-\mathrm{CaO}_{\mathrm{f}}\right)\right] \\
& -[(7.6 \times \mathrm{S})+(6.72 \times \mathrm{A})+(1.43 \times \mathrm{F})] \\
& \mathrm{C}_{2} \mathrm{~S}(\%)=2.87 \times \mathrm{S}-0.75 \times \mathrm{C}_{3} \mathrm{~S} \\
& \mathrm{C}_{3} \mathrm{~A}(\%)=2.65 \times \mathrm{A}-1.69 \times \mathrm{F} \\
& \mathrm{C}_{4} \mathrm{AF}(\%)=3.04 \times \mathrm{F}
\end{aligned}
$$

Where, $\mathrm{C}=\mathrm{CaO}, \mathrm{S}=\mathrm{SiO}_{2}, \mathrm{~A}=\mathrm{Al}_{2} \mathrm{O}_{3}, \mathrm{~F}=\mathrm{Fe}_{2} \mathrm{O}_{3}, \mathrm{~S}=\mathrm{SO}_{3}$, $\mathrm{CaO}_{\mathrm{f}}=$ free lime and LOI: loss on ignition at $975{ }^{\circ} \mathrm{C}$.

\section{Results and discussion}

\subsection{Alumina sludge characterization}

Table 1 gives the chemical composition of the alumina sludge obtained by XRF analysis. The main oxides identified were: $\mathrm{SiO}_{2}, \mathrm{Al}_{2} \mathrm{O}_{3}$ and $\mathrm{Fe}_{2} \mathrm{O}_{3}$ and $\mathrm{CaO}$. The high alumina contents are attributed to the addition of aluminum sulphate during the water coagulationflocculation step [1, 2]. The alumina sludge had a very low $\mathrm{SO}_{3}$ contents and the $\mathrm{P}_{2} \mathrm{O}_{5}$ concentration was about $0.16 \%$ by weight. The loss on ignition of the alumina sludge is $33.14 \%$ and the major compounds from the residues of the flocculent and the clay must not undergo considerable variations.

Fig. 1 shows the X-ray diffractogram of the alumina sludge dried at $105{ }^{\circ} \mathrm{C}$. The crystalline mineral phases identified consists mainly of Muscovite $\left(\mathrm{H}_{2} \mathrm{KAl}_{3}\left(\mathrm{SiO}_{4}\right)_{3}\right)$, Mica (K-Mg-Fe-Al-Si-O-H $\left.{ }_{2} \mathrm{O}\right)$ and Quartz $\left(\mathrm{SiO}_{2}\right)$.

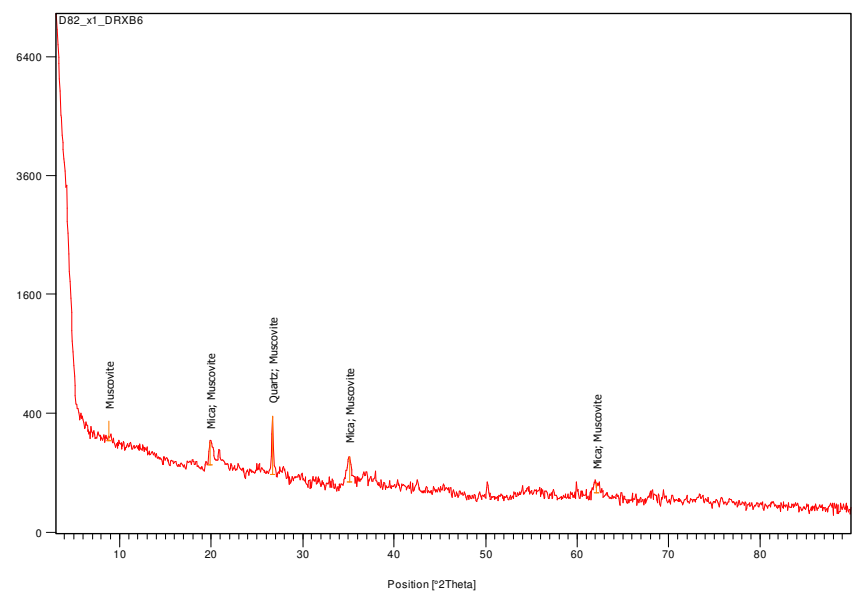

Fig. 1: X-ray diffractogram of alumina sludge dried at $105^{\circ} \mathrm{C}$.

\begin{tabular}{cccccccccccccc}
\hline & $\mathrm{SiO}_{2}$ & $\mathrm{Al}_{2} \mathrm{O}_{3}$ & $\mathrm{Fe}_{2} \mathrm{O}_{3}$ & $\mathrm{CaO}$ & $\mathrm{MgO}$ & $\mathrm{SO}_{3}$ & $\mathrm{~K}_{2} \mathrm{O}$ & $\mathrm{TiO}_{2}$ & $\mathrm{MnO}_{2}$ & $\mathrm{P}_{2} \mathrm{O}_{5}$ & $\mathrm{Na}_{2} \mathrm{O}$ & $\mathrm{SrO}^{\mathrm{L} . \mathrm{O} . \mathrm{I}}$ \\
\hline Alumina sludge & 13.52 & 47.67 & 1.13 & 2.49 & 0.05 & 0.18 & 0.56 & 0.12 & 0.90 & 0.16 & -0.04 & 0.016 & 33.14 \\
\hline
\end{tabular}

L.O.I: Loss on ignition at $975^{\circ} \mathrm{C}$. 


\subsection{Influence of additional alumina sludge on physic-chemical characteristics of cement elaborated.}

\subsubsection{X-ray fluorescence analysis and free lime contents}

The chemical and mineralogical composition of various cements obtained with the addition of alumina sludge $(5,10,15,20$ and 25\%) is shown in Table 1. It is found that the replacement of 5\% alumina sludge by weight cement 52. $\mathrm{N}$ did not induce any qualitative impact on the chemical and mineralogical composition phases formulated by Bogue's equations. Compared with the chemical composition of industrial Portland cement, typical oxides such as $\mathrm{SiO}_{2}, \mathrm{Al}_{2} \mathrm{O}_{3}, \mathrm{Fe}_{2} \mathrm{O}_{3}$ and $\mathrm{CaO}$ are present in concentrations similar to industrial Portland cement [14]. The $\mathrm{C}_{3} \mathrm{~S}$ and $\mathrm{C}_{2} \mathrm{~S}$ contents are close to those obtained in a regular Portland cement [15]. On the other hand, the substitution of $10-25 \%$ by weight seems to affect the chemical and mineralogical composition of cements. The cements produced by the addition of the alumina sludge were characterized by higher $\mathrm{Al}_{2} \mathrm{O}_{3}$ contents compared to cement $52.5 \mathrm{~N}$. This is due of course to the high $\mathrm{Al}_{2} \mathrm{O}_{3}$ proportion which is the main constituent in the alumina sludge. Due to the same reason, higher contents of the $\mathrm{C}_{3} \mathrm{~A}$ phase were also calculated for these samples.
The Alite $\left(\mathrm{C}_{3} \mathrm{~S}\right)$ contents decreased with the increase in the addition of alumina sludge which justified the increase in $\mathrm{C}_{3} \mathrm{~A}$ contents. The incorporation of the alumina sludge does not seem to influence the final contents of free lime. The quantity of free lime in our samples remains less than $2 \%$ which is in agreement with the quantity of free lime of industrial Portland cement. Moreover, this result is also consistent with the amount of free lime in Portland cement reported in the literature [16].

\subsubsection{X-ray diffraction analysis}

The cement XRD of $52.5 \mathrm{~N}$ references and cements produced by the addition of different percentages of the alumina sludge are given in Fig. 2. As can be seen in Fig. 2 the addition of $5-15 \%$ of alumina sludge did not affect the formation of the mineralogical phases and therefore does not entail the formation of new minerals in the cements produced. In these cements, the main mineralogical phases are: $\mathrm{C}_{3} \mathrm{~S}, \mathrm{C}_{2} \mathrm{~S}, \mathrm{C}_{3} \mathrm{~A}, \mathrm{C}_{4} \mathrm{AF}, \mathrm{SiO}_{2}$, $\mathrm{CaCO}_{3}, \mathrm{CaSO}_{4} \cdot 2 \mathrm{H}_{2} \mathrm{O}$. The prepared cements were found to have Alite with monoclinic form $\left(\mathrm{Ca}_{3} \mathrm{SiO}_{5}\right)$. Belite was found to crystallize in a monoclinic system, similar to the polymorphous form $\mathrm{Ca}_{2} \mathrm{SiO}_{4}$ ( $\beta$-Belite) and Celite $\left(\mathrm{Ca}_{3} \mathrm{Al}_{2} \mathrm{O}_{6}\right)$ also has the monoclinic form. As the addition of the alumina sludge increases the peak intensity of the Alite and calcite decreases and the $\mathrm{C}_{2} \mathrm{~S}$ lines predominate.

Table 2. Chemical analysis of cements.

\begin{tabular}{|c|c|c|c|c|c|c|}
\hline & CEM $52.5 \mathrm{~N}$ & $\mathrm{CEM}+5 \% \mathrm{AS}$ & $\mathrm{CEM}+10 \% \mathrm{AS}$ & $\mathrm{CEM}+15 \% \mathrm{AS}$ & $\mathrm{CEM}+20 \% \mathrm{AS}$ & $\mathrm{CEM}+25 \% \mathrm{AS}$ \\
\hline \multicolumn{7}{|c|}{ Chemical composition } \\
\hline $\mathrm{SiO}_{2}$ & 19.60 & 18.55 & 18.98 & 18.93 & 18.26 & 17.69 \\
\hline $\mathrm{Al}_{2} \mathrm{O}_{3}$ & 4.33 & 5.98 & 8.03 & 10.02 & 11.80 & 13.31 \\
\hline $\mathrm{Fe}_{2} \mathrm{O}_{3}$ & 2.99 & 2.91 & 2.86 & 2.81 & 2.69 & 2.47 \\
\hline $\mathrm{CaO}$ & 60.88 & 58.55 & 55.46 & 53.12 & 49.6 & 47.38 \\
\hline $\mathrm{MgO}$ & 1.64 & 1.56 & 1.49 & 1.47 & 1.32 & 1.25 \\
\hline $\mathrm{SO}_{3}$ & 1.90 & 1.87 & 1.54 & 1.04 & 0.70 & 0.38 \\
\hline $\mathrm{K}_{2} \mathrm{O}$ & 0.66 & 0.67 & 0.65 & 0.64 & 0.63 & 0.62 \\
\hline $\mathrm{TiO}_{2}$ & 0.32 & 0.30 & 0.31 & 0.29 & 0.28 & 0.27 \\
\hline $\mathrm{MnO}$ & 0.07 & 0.15 & 0.24 & 0.31 & 0.39 & 0.48 \\
\hline $\mathrm{P}_{2} \mathrm{O}_{5}$ & 0.24 & 0.23 & 0.23 & 0.23 & 0.23 & 0.23 \\
\hline $\mathrm{Na}_{2} \mathrm{O}$ & -0.02 & -0.02 & -0.02 & -0.02 & -0.023 & -0.02 \\
\hline $\mathrm{SrO}$ & 0.064 & 0.057 & 0.055 & 0.054 & 0.053 & 0.050 \\
\hline $\mathrm{CaO}_{\mathrm{f}}$ & 1.96 & 1.456 & 0.672 & 0.504 & 0.336 & 0.28 \\
\hline LOI & 7.22 & 9.08 & 10.08 & 10.99 & 13.96 & 15.78 \\
\hline \multicolumn{7}{|c|}{ Estimated mineralogical composition } \\
\hline $\mathrm{C}_{3} \mathrm{~S}$ & 60.08 & 47.69 & 19.15 & -1.91 & -22.00 & -35.58 \\
\hline $\mathrm{C}_{2} \mathrm{~S}$ & 10.86 & 17.18 & 39.92 & 55.68 & 68.90 & 77.50 \\
\hline $\mathrm{C}_{3} \mathrm{~A}$ & 6.41 & 10.93 & 16.42 & 21.80 & 26.74 & 31.09 \\
\hline $\mathrm{C}_{4} \mathrm{AF}$ & 9.11 & 8.87 & 8.72 & 8.55 & 8.17 & 7.51 \\
\hline
\end{tabular}

LOI: Loss on ignition at $975^{\circ} \mathrm{C}$. 


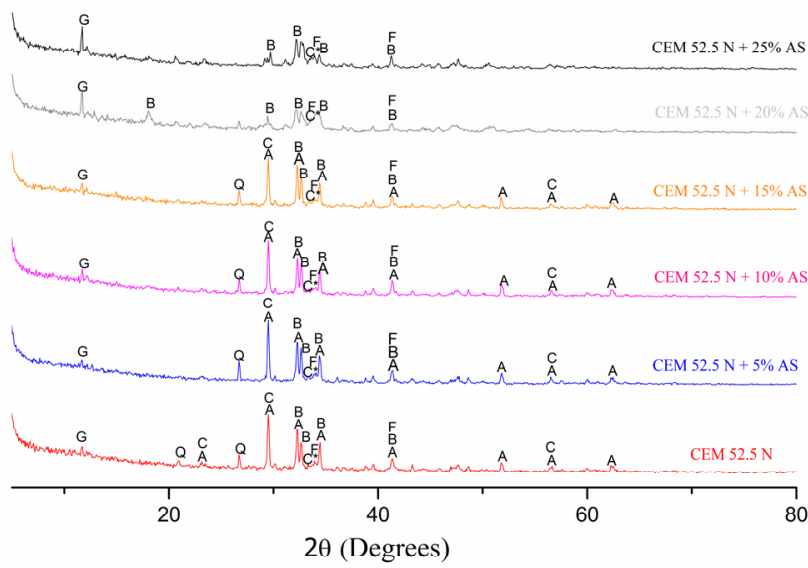

Fig. 2: $\mathrm{X}$-ray diffractogram cements (A: Alite $\left(\mathrm{Ca}_{3} \mathrm{SiO}_{5}\right), \mathrm{B}$ : Belite $\left(\mathrm{Ca}_{2} \mathrm{SiO}_{4}\right), \mathrm{C}$ : Calcite $\left(\mathrm{CaCO}_{3}\right), \mathrm{C}^{*}$ : Celite $\left(\mathrm{Ca}_{3} \mathrm{Al}_{2} \mathrm{O}_{6}\right)$, F: Ferrite $\left(4 \mathrm{CaOAl}_{2} \mathrm{O}_{3} \mathrm{Fe}_{2} \mathrm{O}_{3}\right)$; Q: Quartz $\left(\mathrm{SiO}_{2}\right)$ and $\mathrm{G}$ : gypsum $\left.\left(\mathrm{CaSO}_{4} \cdot 2 \mathrm{H}_{2} \mathrm{O}\right)\right)$.

\subsubsection{Physical and mechanical properties of cement mortars produced}

The flexural and compressive strengths were measured after being cured for 2, 7 and 28 days, are given in Fig. 3/4, respectively. The mortar based cements produced after 2 days of curing are presented in Fig. 5.

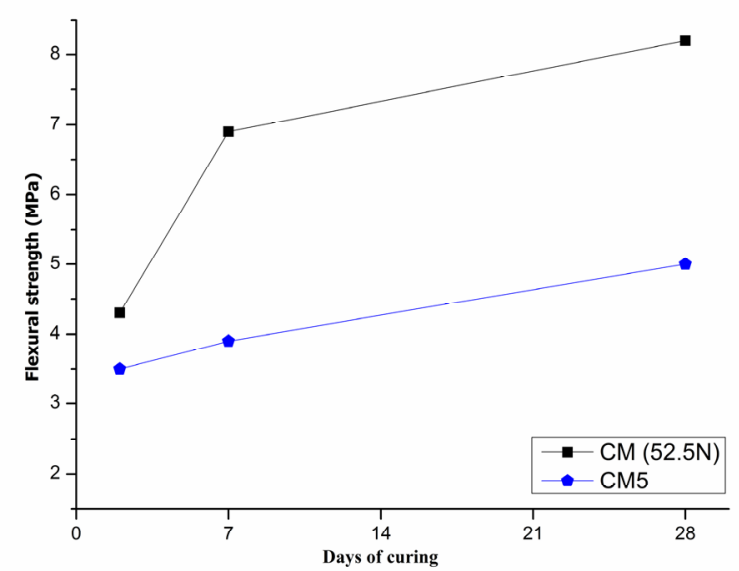

Fig. 3. Flexural strength results of the cement mortar after different curing times.

These compressive strengths were compared with the compressive strength of ordinary Portland cement 52.5 N. Comparison of the results shows that the flexural and compressive strength of the mortar with 5\% alumina sludge was lower than that of ordinary Portland cement $52.5 \mathrm{~N}$ at all hydration stages. In this case the sludge hydrates slowly and the products obtained during the hydration are reduced when the alumina sludge increases. Mortars based on 10 up to $25 \%$ alumina sludge with low resistance are associated with the decrease in the amount of $\mathrm{C}_{3} \mathrm{~S}$ responsible for the development of resistances during the first four weeks. The results indicate that all mortars with a 5\% replacement of alumina sludge can be classified as Portland cements of category $32.5 \mathrm{R}$ according to EN197-1[12].

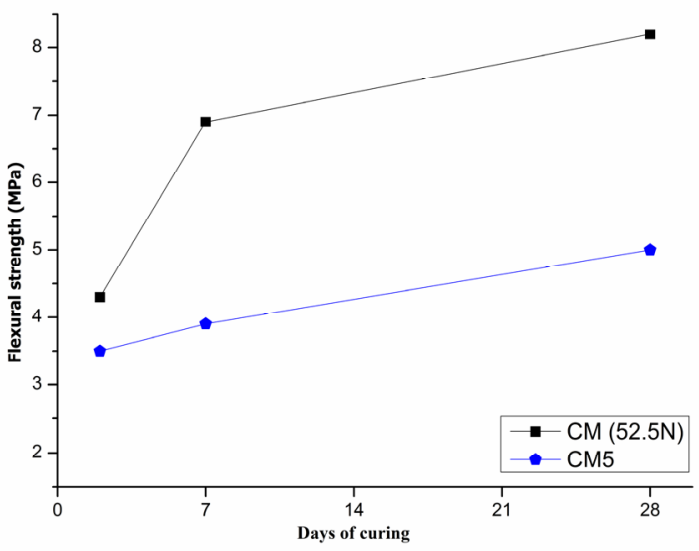

Fig. 4. Compressive strength results of the cement mortar after different curing times.

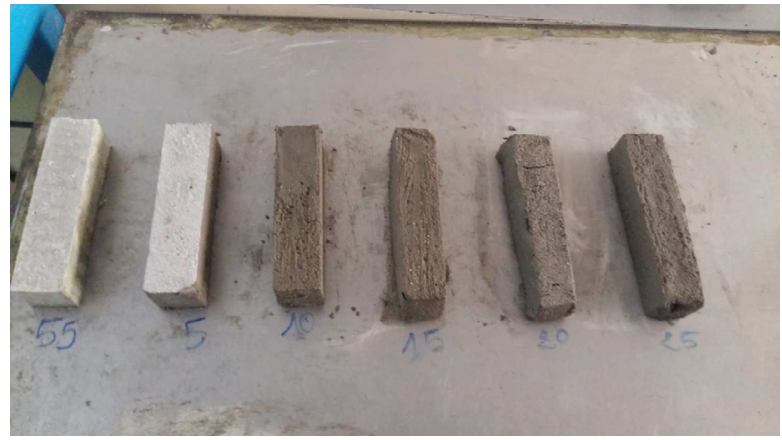

Fig. 5. Images of mortar based cements produced after 2 days of curing. (55: CEM 52.5N ( $\left.\mathrm{CPJ}_{55}\right)$; 5 : CEM $52.5 \mathrm{~N}$ $+5 \%$ AS; $10:$ CEM $52.5 \mathrm{~N}+10 \%$ AS; $15:$ CEM $52.5 \mathrm{~N}+$ $15 \%$ AS; 20: CEM 52.5N + 20\% AS; 25: CEM 52.5N + $25 \%$ AS.

\section{Conclusion}

The direct use of alumina sludge mineral waste as an addition to Portland cement might lead to environmental protection and sustainable development and allows compensating the needs of $\mathrm{Al}_{2} \mathrm{O}_{3}$ and $\mathrm{Fe}_{2} \mathrm{O}_{3}$ in cements. It has been found in the present study that in 28 days, all mortars produced with a 5\% replacement of alumina sludge can be classified as Portland cements of category $32.5 \mathrm{R}$. The addition of alumina sludge also contributes to the reduction of the total cost of the cement since the 
grinding of alumina sludge is much less energy consuming thus contributing in the reduction of the energy requirements of the formation of Portland cement.

\section{References}

1. M. Dahhou, M. El Moussaouiti, A. Benlalla, A. El Hamidi, M. Taibi, M. A. Arshad, Waste Biomass Valor. 7, 5 (2016)

2. M. Dahhou, M. El Moussaouiti, M. El Morhit, S Gamouh, S Moustahsine, J. Taib. Univ. Sci. 11, 5 (2017)

3. M. Smol, J. Kulczycka, A. Henclik, K. Gorazda, Z. Wzorek, J. Clean. Prod. 95 (2015)

4. W.J. Wang, C.D. Wang, T.C. Lee, C.C. Chang, Constr. Build. Mater. 56 (2014)

5. Y. Lin, S. Zhou, F. Li, Y. Lin, J. Hazard. Mater. 213-214 (2012)

6. R.M.R. Zamora, O.C. Alfaro, N. Cabirol, F.E. Ayala, A.D. Moreno, Am. J. Environ. Sci. 4, 3 (2008)

7. S. Yan, K. Sagoe-Crentsil, G. Shapiro, J. ENVIRON. MANAGE. 92 (2011)

8. N.H. Rodríguez, S. Martínez-Ramírez, M.T. BlancoVarela, M. Guillem, J. Puig, E. Larrotcha, J. Flores,. Cement Concrete Res. 40, 5 (2010)

9. O. Rodríguez, L. Kacimi, A. López-Delgado, M. Frías, A. Guerrero, Constr. Build. Mater. 40 (2013)

10. H. El-Didamony, K.A. Khalil, M. Heikal, HBRC J. 15 (2014)

11. W. Piasta, M. Lukawska, Procedia engineer. 161 (2016)

12. Afnor. EN 197-1, Cement composition, specifications and conformity criteria for common cements, (2000)

13. P. Stutzman, A. Heckert, A. Tebbe, S. Leigh, Cement Concrete Res. 61-62 (2014)

14. A. Bordy, A. Younsi, S. Aggoun, B, Fiorio, Constr. Build. Mater. 132 (2017)

15. X. Cai, Z. He, S. Tang, X. Chen, Constr. Build. Mater. 127 (2016)

16. AS-D-G. Vilaplana, V.J. Ferreira, A.M. LópezSabirón, A. Aranda-Usón, C. Lausín-González, C. Berganza-Conde, G. Ferreira, Constr. Build. Mater. 94 (2015) 